\title{
Isothermal and Batch Adsorption Studies of Malachite Green Oxalate Dye onto Activated Carbon from Snail Shell
}

\author{
Ikhazuangbe P.M.O. ${ }^{1}$, Eruotor M.O. ${ }^{2}$ \\ ${ }^{1}$ Chemical engineering department, Federal University of Technology, Owerri, Nigeria \\ ${ }^{2}$ Physics with electronics department, Western Delta University, Oghara, Nigeria
}

\begin{abstract}
Adsorption efficiency, kinetic and thermodynamic studies of the adsorption of Malachite green oxalate onto activated carbon from snail shell was carried out. The cleaned Snail shell was carbonized at $400^{\circ} \mathrm{C}$, crushed and sieved before it was activated with $0.1 \mathrm{~m}$ $\mathrm{HCl}$ at $800^{\circ} \mathrm{C}$ in a furnace. Batch adsorption experiment was carried out at variable concentration, time and temperature while other factors are kept constant. The adsorption isotherms used show that the correlation coefficient of Freundlich isotherm is closer to unity compare to that of Langmuir isotherm. The adsorption follows the Pseudo second order kinetic with adsorption capacity of $1.7544(\mathrm{mg} / \mathrm{g})$ and rate constant of $0.471(\mathrm{~g} / \mathrm{mg} . \mathrm{min})$. The thermodynamic parameters: change in enthalpy, $\Delta H=15.90 \mathrm{KJ} / \mathrm{mol}$, change in entropy $\Delta S=$ $60.16 \mathrm{~J} / \mathrm{mol} . K$ and the change in Gibbs free energy $\Delta G=-$ $1.69,-2.98,-3.64,-3.24,-3.43$ and $-3.51 \mathrm{KJ} / \mathrm{mol}$ at 303 , $308,313,318,323$ and $328 \mathrm{~K}$ respectively. These results show that activated carbon from snail shell has the potential of a good low cost adsorbent for the removal of this hazardous dye from wastewater.
\end{abstract}

Keywords-Adsorption, kinetic, Malachite green oxalate, snail shell, thermodynamic.

\section{INTRODUCTION}

The textile, paper, printing and dye industries consume large quantities of water at its different steps of dyeing and finishing processes. Due to the large volume of water consumption, the production of huge volume of wastewater is inevitable. Generally, the wastewater from printing and dyeing units in these plants contain residue of dyes and chemicals [5]. The presence of these dyes in wastewater is not desirable because of their toxic nature to the life and environment into which they are discharged. Therefore, the removal of such compounds from wastewater is a vital task.
Adsorption process using activated carbons is widely used to remove pollutants from wastewaters. However, commercially available activated carbon is expensive. In the last years, special emphasis on the preparation of activated carbons from several agricultural by-products has been given, due to the growing interest in low cost activated carbons from renewable, copious, especially for application concerning treatment of wastewater. Researchers have studied the production of activated carbon from palm-tree cobs, plum kernels, cassava peel, bagasse, jute fiber, rice husks, olive stones, date pits, fruit stones and nutshells [2]. In this study, the ability of snail shell carbon to remove Malachite green oxalate by adsorption is been studied. The Langmuir and Freundlich isotherms will used to fit the equilibrium data. Pseudo-first order and pseudo-second order models will be used to fit the experimental data and the thermodynamic study will also be carried out [3].

\section{THEORY}

\subsection{Adsorption kinetics}

The pseudo first order and second order kinetic models need to be tested to determine which model is in good agreement with experiment adsorption capacity $\left(\mathrm{q}_{\mathrm{e}}\right)$ value, thus suggesting which model the adsorption system follows.

2.1.1 Pseudo-first order equation

The Largergren model assumes a first order adsorption kinetics and can be represented by the equation.

$\frac{d q_{t}}{d t}=\mathrm{K}_{1}\left(q_{e}-q_{t}\right)$

$\log \left(\mathrm{q}_{\mathrm{e}}-\mathrm{q}_{\mathrm{t}}\right)=\log \left(\mathrm{q}_{\mathrm{e}}\right)-\frac{K_{1}}{2.303} \mathrm{t}$

The values of $\log \left(\mathrm{q}_{\mathrm{e}}-\mathrm{q}_{\mathrm{t}}\right)$ were linearly correlated with time $t$. The plot of $\log \left(\mathrm{q}_{\mathrm{e}}-\mathrm{q}_{\mathrm{t}}\right)$ versus $\mathrm{t}$ should give a linear relationship from which $\mathrm{K}_{1}$ and $\mathrm{q}_{\mathrm{e}}$ can be determined from the slope and intercept of the plot, respectively.

2.1.2 Pseudo-second order equation

The pseudo-second-order adsorption kinetic rates equation is expressed as 
$\frac{t}{q_{t}}=\frac{1}{K_{2} q_{e}^{2}}+\frac{1}{q_{e}} \mathrm{t}$

Where $K_{2}$ is the rate constant of the pseudo second order adsorption (g/mg.min). The plot of $\left(\mathrm{t} / \mathrm{q}_{\mathrm{t}}\right)$ and $\mathrm{t}$ of equation 3 should give a linear relationship from which $\mathrm{q}_{\mathrm{e}}$ and $\mathrm{K}_{2}$ can be determined [4].

\subsection{Thermodynamic studies}

The determination of the basic thermodynamic parameters such as enthalpy $(\Delta \mathrm{H})$, Gibb's free energy $(\Delta \mathrm{G})$ and entropy $(\Delta S)$ of the adsorption is important, as it determines if the process is favorable or not from thermodynamic point of view, to assess the spontaneity of the system and to ascertain the exothermic or endothermic nature of the process. An adsorption process is generally considered as physical if $\Delta \mathrm{H}<84 \mathrm{~kJ} \mathrm{~mol}^{-1}$ and as chemical when $\Delta \mathrm{H}$ lies between 84 and $420 \mathrm{~kJ} \mathrm{~mol}^{-1}$ [9].

Using equations 4 to 6

$\Delta \mathrm{G}=-\mathrm{RTInK}_{\mathrm{d}}$

$\mathrm{K}_{\mathrm{d}}=\frac{q e}{C e}$

$\mathrm{InK}_{\mathrm{d}}=\frac{\Delta S}{R}-\frac{\Delta H}{R T}$

The thermodynamic parameters of the adsorption process were determined from the experimental data obtained at various temperatures.

Where $K_{d}$ is the distribution coefficient for the adsorption, $\mathrm{q}_{\mathrm{e}}$ is the amount of dye (mg/l) adsorbed at equilibrium, $\mathrm{C}_{\mathrm{e}}$ is the equilibrium concentration $(\mathrm{mg} / \mathrm{l})$ of the dye in solution, $\mathrm{T}$ is the absolute temperature in Kelvin, $\mathrm{R}$ is gas constant (8.314 J.K $\left.\mathrm{K}^{-1} \cdot \mathrm{mol}^{-1}\right), \Delta G, \Delta H$, and $\Delta S$ are change in Gibbs free energy, change in enthalpy and entropy change respectively. The values of enthalpy change $(\Delta H)$ and entropy change $(\Delta S)$ are obtained from the slope and intercept of $\ln K_{d}$ versus $1 / \mathrm{T}$ plots [1].

\subsection{Adsorption isotherm}

2.3.1 Langmuir adsorption isotherm (model)

The Langmuir equation is probably the best known and most widely applied adsorption isotherm. It is represented as follows in equation 7

$\frac{C e}{q e}=\frac{1}{b Q o}+\frac{C e}{Q o}$

From which values of $\mathrm{Q}_{\mathrm{o}}$ and $\mathrm{b}$ can be determined from the slope and intercept respectively of the plot of $\mathrm{Ce} / q e$ versus $\mathrm{C}_{\mathrm{e}}$

Where $\mathrm{Q}_{\mathrm{o}}$ and $\mathrm{b}$ are Langmuir constants, $\mathrm{q}_{\mathrm{e}}$ is amount of solute removed or adsorbed at equilibrium. $\mathrm{C}_{\mathrm{e}}$, is equilibrium concentration of mixture.

2.3.2 Freundlich adsorption isotherm (model)
The Freundlich isotherm is an empirical relationship which often gives a more satisfactory model of experimental data. It can be expressed as follows:

$\log q_{e}=\log \left(\mathrm{K}_{\mathrm{f}}\right)+\frac{1}{n} \log \mathrm{C}_{\mathrm{e}}$

Where $\mathrm{C}_{\mathrm{e}}$ and $\mathrm{q}_{\mathrm{e}}$ are equilibrium concentration and adsorption capacity at equilibrium stage, while $\mathrm{K}_{\mathrm{f}}$ and $\mathrm{n}$ are Freundlich constants which incorporates all factors affecting the adsorption process (adsorption capacity and intensity). Values of $\mathrm{K}_{\mathrm{f}}$ and $\mathrm{n}$ can be obtained from the intercept and slope of a plot of adsorption capacity, $\mathrm{q}_{\mathrm{e}}$ against equilibrium concentration $\mathrm{C}_{\mathrm{e}}[8]$.

\section{MATERIALS AND METHODS}

\subsection{Preparation of adsorbent}

Sample of snail shells were picked from the environment in Elele, Rivers State, Nigeria. The snail shells were washed with tap several times to remove the dust and other watersoluble materials. The process continues until the washing water was colorless, then dried in the open air. The dried snail shells were carbonized in a furnace (SX-5-12) at $400^{\circ} \mathrm{C}$ for 3 hours, the charred were allowed to cool to room temperature and ground. 100 gram of the ground carbonized snail shells was added to $300 \mathrm{ml}$ of $0.1 \mathrm{M} \mathrm{HCl}$ solution, thoroughly mixed and heated until it formed slurry. The slurry was transferred to a crucible and heated in a furnace (SX-5-12) at $800^{\circ} \mathrm{C}$ for 3 hours, allowed to cool to room temperature and washed with de-ionized water, dried in an oven at $110^{\circ} \mathrm{C}$ for 2 hours [7].

\subsection{Preparation of adsorbate}

The malachite green oxalate used is of laboratory grade (KEM LIGHT, India). The solution was prepared in deionized water from Ion-exchange (Indian) Ltd, Eleme, Port Harcourt, Nigeria. $150 \mathrm{mg}$ of the dye was dissolved in $1000 \mathrm{ml}$ of de-ionized water to prepare the standard solution. Experimental solutions of the desired concentrations were obtained by successive dilutions with de-ionized water.

\subsection{Adsorption experiment}

$1000 \mathrm{mg}$ of the activated carbon of snail shell was mixed with $50 \mathrm{ml}$ of malachite green oxalate solution of the desired concentrations $(25,50,75,100,125$ and $150 \mathrm{mg} / \mathrm{L})$ at $30^{\circ} \mathrm{C}$ in a temperature controlled water bath with constant shaking. The samples were withdrawn after 30 minutes and dye solutions were separated from the adsorbent using Whatmann filter paper. The concentration of the filtrate was measured with a UV spectrophotometer (2OD) at $618 \mathrm{~nm}$. The experiment was repeated using $1000 \mathrm{mg}$ of the activated carbon with $50 \mathrm{ml}$ of $50 \mathrm{mg} / \mathrm{L}$ concentration of malachite green oxalate solution at $30^{\circ} \mathrm{C}$ in a temperature controlled 
water bath with constant shaking. The samples were withdrawn after 30,60, 90, 120, 150 and 180minutes respectively and filtered using Whatmann filter paper. The concentration of the filtrate was measured with a UV spectrophotometer (2OD) at $618 \mathrm{~nm}$. Again 1000mg of the activated carbon mixed with $50 \mathrm{ml}$ of $50 \mathrm{mg} / \mathrm{L}$ concentration of malachite green oxalate solution at 30, 35, 40, 45, 50 and $55^{\circ} \mathrm{C}$ in a temperature controlled water bath (DK - 420) with constant shaking was also carried out. The samples were withdrawn after 30minutes respectively filtered and the concentration measured.

The adsorption amount of malachite green oxalate dye adsorbed onto the snail shell adsorbent at equilibrium was calculated with the following equation:

$q_{e}=\frac{\left(C_{o}-C_{e}\right) V}{X}$

Where $\mathrm{C}_{0}(\mathrm{mg} / \mathrm{L})$ and $\mathrm{C}_{\mathrm{eq}}(\mathrm{mg} / \mathrm{L})$ are the initial and equilibrium concentration of the dyes, V (L) is the volume of solution, $\mathrm{X}(\mathrm{g})$ is the weight of adsorbent in one container.

The percentage of snail shell adsorbed was calculated as:

$\%$ adsorbed $=\frac{\left(C_{o}-C_{e}\right)}{C_{o}} \times 100$

\section{RESULTS}

The results of the adsorption experiment are presented graphically in the figures below.

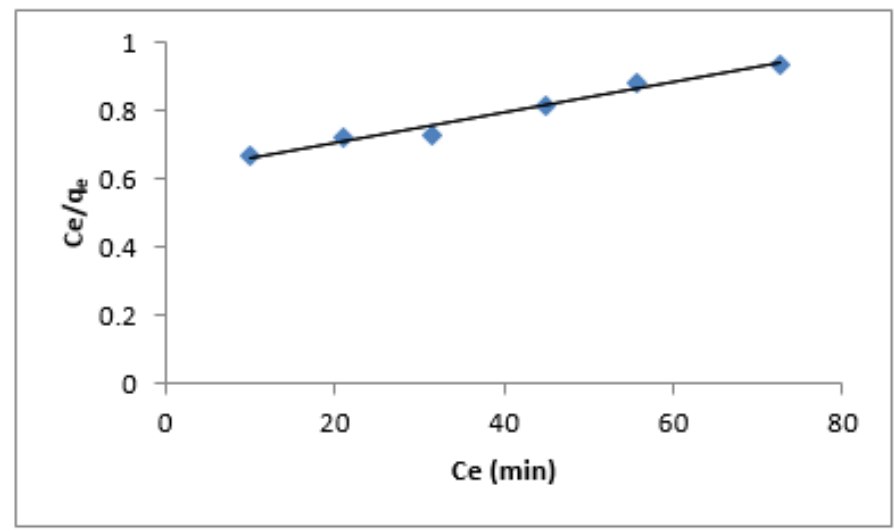

Fig. 1: Langmuir model

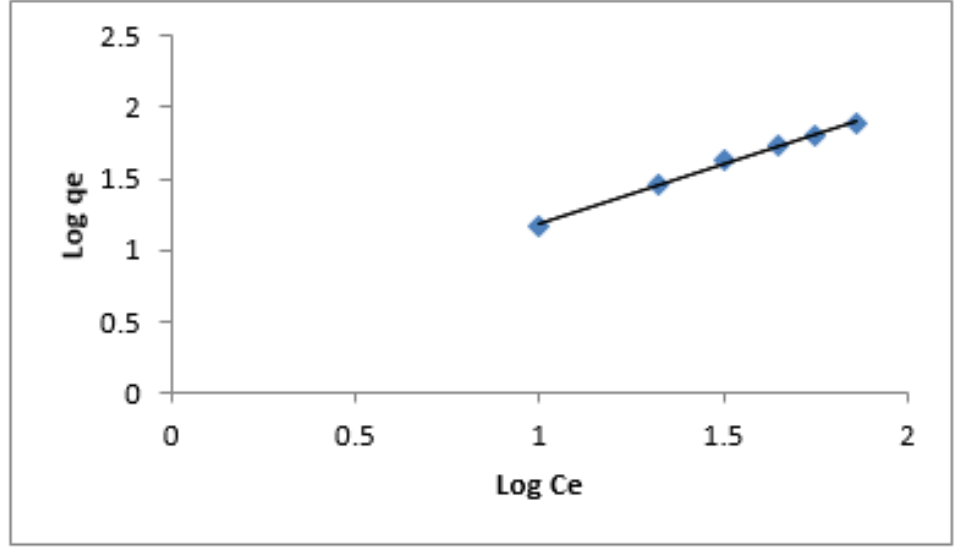

Fig.2: Freundlich model

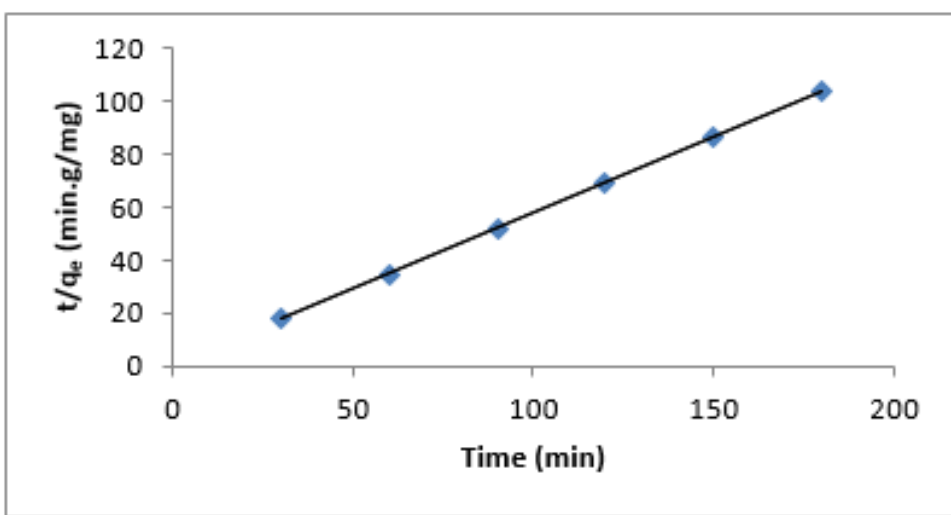

Fig. 3: Pseudo second order reaction

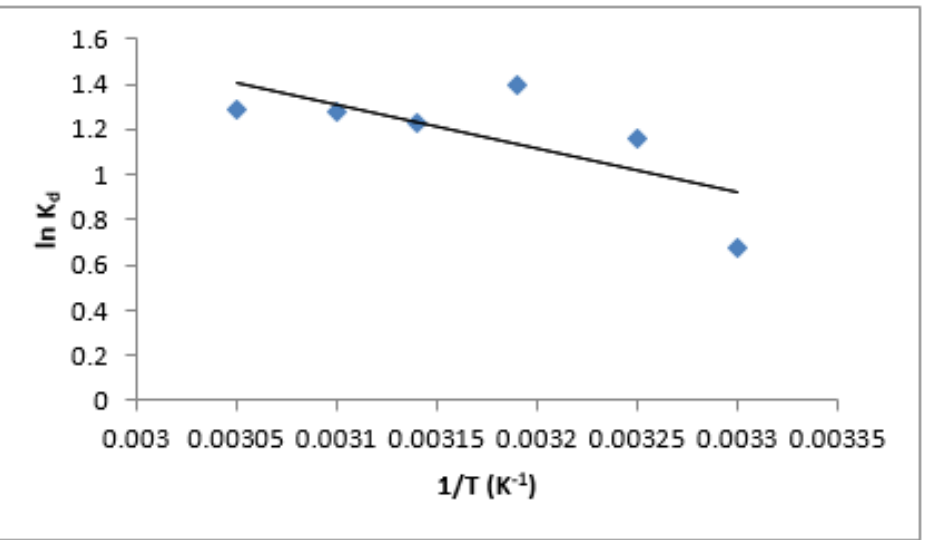

Fig. 4: Vant's Hoff model 
Table.1: Adsorption efficiency

\begin{tabular}{|l|l|l|l|l|l|}
\hline \multicolumn{2}{|c|}{ Variable time } & \multicolumn{2}{c|}{ Variable temperature } & \multicolumn{2}{c|}{ Variable concentration } \\
\hline Time (min) & $\%$ Adsorption & Temp ${ }^{\circ} \mathrm{C}$ & $\%$ Adsorption & Conc. (mg/L) & \% Adsorption \\
\hline 30 & 64.73 & 30 & 64.73 & 25 & 81.09 \\
\hline 60 & 75.82 & 35 & 76.55 & 50 & 79.27 \\
\hline 90 & 76.13 & 40 & 76.91 & 75 & 73.33 \\
\hline 120 & 76.36 & 45 & 78.18 & 100 & 72.45 \\
\hline 150 & 76.36 & 50 & 78.91 & 125 & 71.71 \\
\hline 180 & 76.36 & 55 & 79.09 & 150 & 70.91 \\
\hline
\end{tabular}

Table.2: Adsorption isotherm constants for coconut fibre activated carbon

\begin{tabular}{|l|l|l|l|l|l|}
\hline \multicolumn{3}{|c|}{ Langmuir } & \multicolumn{3}{c|}{ Freundlich } \\
\hline Qo $\left(\frac{g}{m g}\right)$ & $\mathrm{b}\left(\frac{m g}{l}\right)$ & $\mathrm{R}^{2}$ & $\mathrm{~K}_{\mathrm{f}}\left(\frac{m g}{g}\right)$ & $\mathrm{n}\left(\frac{l}{g}\right)$ & $\mathrm{R}^{2}$ \\
\hline 250 & 0.0065 & 0.978 & 2.3067 & 1.206 & 0.995 \\
\hline
\end{tabular}

Table.3: Thermodynamic parameters for erythrosine adsorption by activated carbon

\begin{tabular}{|c|c|c|c|}
\hline Temperature $(\mathrm{K})$ & $\Delta G(\mathrm{KJ} / \mathrm{mol})$ & $\Delta \mathrm{H}(\mathrm{KJ} / \mathrm{mol})$ & $\Delta \mathrm{S}(\mathrm{J} / \mathrm{mol} . \mathrm{K})$ \\
\hline 303 & -1.69 & \multirow[t]{6}{*}{15.90} & \multirow[t]{6}{*}{60.16} \\
\hline 308 & -2.98 & & \\
\hline 313 & -3.64 & & \\
\hline 318 & -3.24 & & \\
\hline 323 & -3.43 & & \\
\hline 328 & -3.51 & & \\
\hline
\end{tabular}

\section{DISCUSSION}

The efficiency of the adsorption presented in table 1, shows that adsorption increases as time increases until 120min when the active sites were filled, then the adsorption efficiency becomes constant. The table also shows that adsorption increases with increase temperature, but after $35^{\circ} \mathrm{C}$, increasing the temperature will no longer be economical. As the concentration of the adsorbate is increased, the efficiency of adsorption decreases, though highest at $25 \mathrm{mg} / \mathrm{l}$, but it is more economical with $50 \mathrm{mg} / 1$. The values of the adsorption models presented in table 2 shows that the correlation coefficient of Freundlich isotherm is closer to 1 than that of Langmuir, indicating that it a heterogeneous adsorption process.

The kinetic of adsorption of Malachite green oxalate onto snail shell was studied using pseudo first-order and secondorder equations for the examined system. The pseudo second-order kinetic model provided the best correlation for the experimental data.

From the thermodynamic point of view, the positive value of $\Delta \mathrm{H}$ indicates that the adsorption of Malachite green oxalate on snail shell is endothermic and a physical process. The positive value of $\Delta \mathrm{S}$ shows the existence of structural changes at the solid-liquid interface and $\Delta \mathrm{S}$ favors ion exchange and stability of adsorption. 
Table.4: Adsorption capacities of some adsorbents for MG oxalate removal

\begin{tabular}{|l|l|l|l|}
\hline Adsorbent & $\mathrm{T}^{\circ} \mathrm{C}$ & Adsorption capacity(mg/g) & Reference \\
\hline Rattan sawdust & 30 & 22.4 & Hameed and El-Khaiary (2008) \\
\hline Prawn-Carbon & 30 & 1.5249 & Santhi (2009) \\
\hline Prawn-Raw & 30 & 5.6635 & Santhi (2009) \\
\hline Activated charcoal & & 0.180 & Iqba and Ashiq (2007) \\
\hline Sugar cane dust & & 4.88 & Khattri and Singh (1999) \\
\hline Bentonite & & 178.6 & Bulut etal (2008) \\
\hline Nickel ferrite & & 4.67 & Manohar (2015) \\
\hline Wood apple shell & 25 & 34.56 & Ashish etal. (2014) \\
\hline Carbon prepared from Borassus bark & 30 & 20.70 & Arivoli et al. (2009) \\
\hline Carbon prepared from Arundo donax root & 30 & 8.69 & Zhang et al. (2008) \\
\hline Periwinkle shell & 30 & 1.96 & Ikhazuangbe etal, (2017) \\
\hline Coconut fibre & 30 & 1.88 & Ikhazuangbe etal, (2017) \\
\hline Snail shell & 30 & 1.75 & Present \\
\hline
\end{tabular}

Table.5: Enthalpy and Entropy change of some adsorbent for the dyes

\begin{tabular}{|l|l|l|l|}
\hline Adsorbent & \multicolumn{1}{|c|}{$\Delta \mathrm{H}^{\mathrm{o}}$} & \multicolumn{1}{|c|}{$\Delta \mathrm{S}^{\mathrm{o}}$} & \multicolumn{1}{c|}{ Reference } \\
\hline Thevetia peruviana & 61.127 & 227.0 & Baseri et al, (2012) \\
\hline Pandanus leaves & 60.762 & 231.4 & Hema and Arivoli (2008) \\
\hline Bentonite & 13.21 & 62.85 & Bulut et al, (2008) \\
\hline Wood apple shell & 1.581 & 6.375 & Ashish et al, (2014) \\
\hline Coconut fibre & 20.45 & 74.34 & Ikhazuangbe etal, (2017) \\
\hline Periwinkle shell & 19.74 & 72.21 & Ikhazuangbe etal, (2017) \\
\hline Snail shell & 15.90 & 60.16 & Present \\
\hline
\end{tabular}

\section{CONCLUSION}

From the adsorption efficiency, kinetic and thermodynamic studies of the adsorption of Malachite green oxalate onto activated carbon from snail shell studied, the results obtained from the analysis show that snail shell has good potential as low cost adsorbent for the removal of this hazardous dye from wastewater.

\section{ACKNOWLEDGEMENTS}

The authors sincerely acknowledge the following people: Mr. Ikhazuangbe Benson T, PPMC-NNPC, Aviele pump station, for his financial assistance. Mr. Osibanjo Oluwakemi O, NAPIMS-NNPC, Lagos, for his financial assistance. Mr. Adeleke Kolapo and Mr. Adegbemi Jacob, of Pharmacognosy and Pharmaceutical technology department respectively, Madonna University, Elele, for their technical support. Mr. Daramola Abayomi, of Ionexchange (Indian) Ltd, Eleme, Port Harcourt, for his material assistance.

\section{REFERENCES}

[1] B. Emrah, O. Mahmut, and S.I. Ayhan, "Adsorption of malachite green onto bentonite: Equilibrium and kinetic studies and process design," Microporous And Mesoporous materials, Vol. 115, pp. 234-246

[2] B.H. Hameed, A.T.M. Din, and A.L. Ahmad, "Adsorption of methylene blue onto bamboo-based activated carbon: Kinetics and equilibrium studies," Journal of hazardous materials, 2006;

[3] B.H. Hameed, and M.I. El-Khaiary, "Malachite green adsorption by Rattan Sawdust: Isotherm, kinetic and mechanism modeling". Journal of Hazardous Materials, Vol. 159, 2008, pp. 574-579.

[4] D. Hakan, D. İlknur, and K. Belgin, "Adsorption of Textile Dye onto Activated Carbon Prepared from Industrial. Giresul," Turkey: J. Int. Environmental Application \& Science, 2008.

[5] D.B. Adie, C.A Okuofu, and C. Osakwe, "Isothermal and batch adsorption Studies of the use of Borassus Aethiopium and Cocos Nucifera for wastewater treatment," America International Journal of 
Contemporary research, Vol. 2. (7), 2012, pp. 119 130.

[6] Hema, M., and Arivoli, S., "Adsorption kinetics and thermodynamics of Malachite green dye unto acid activated low cost carbon". J. Appl. Sci. Environ. Manage, Vol. 12(1), 2008, pp. $43-51$.

[7] M. Arami, N.Y. Limaee, N.M. Mahmoodi, "Evaluation of the adsorption kinetics and equilibrium for the potential removal of acid dyes using a biosorbent," Chem. Eng. J, Vol. 139, 2008, pp. 2-10.

[8] M. Pedram, M. Parvini and Z.M. Hassan, "Removal of erythrosine dyes from aquatic environment using Ziziphus Nummularia kernel". Iranica journal of Energy \& Environment, Vol. 5. (4), 2014, pp. 400406.

[9] P.M.O. Ikhazuangbe, F.L. Kamen, C.A. Okwara, P.I. Oghome and S.O. Opebiyi, "Adsorption of malachite green oxalate dye onto activated carbon from coconut fibre," International refereed journal of scientific research in engineering, Vol. 2. (4): 2017, pp. $07-12$.

[10] P.M.O. Ikhazuangbe, F.L. Kamen, S.O. Opebiyi, C.A. Okwara and O.E. Onyelucheya, "Kinetic and thermodynamic studies of the adsorption of malachite green oxalate dye onto activated carbon from periwinkle shell", Journal of multidisciplinary engineering science and technology, Vol. 4. (6): 2017. Pp. $1-5$.

[11] R.H. Gumus and I. Okpeku, "Production of Activated Carbon and Characterization from Snail Shell Waste (Helix pomatia)". Advances in Chemical Engineering and Science, Vol. 5. 2015. pp. 51-61.

[12] S. S. Ashish, M. M. Aniruddha, V. J. Vikas, D. R. Prakash, A. A. Mansing, S.K. Sanjay, "Removal of malachite green dye from aqueous solution with adsorption technique using limonia acidissima" (wood apple) shell as low cost adsorbent. Arabian Journal of Chemistry, Vol. 12(19), 2014, pp. 1-10.

[13] S.A. Yahya, A. Rajab and S.A. Samer, "Analyzing adsorption data of erythrosine dye using principal component analysis", Chemical Engineering Journal, Vol. 34, 2012, pp.123- 126,

[14] Z. Zhang, L. Moghaddam, I.M.O. O'Hara, and W.O.S. Doherty, "Congo Red adsorption by ball-milled sugarcane bagasse," Chem. Eng. J, Vol. 178, 2011, pp. $122-128$. 